ENTREPRENEURSHIP AND SUSTAINABILITY ISSUES

ISSN 2345-0282 (online) http://jssidoi.org/jesi/

2019 Volume 6 Number 3 (March)

http://doi.org/10.9770/jesi.2019.6.3(4)

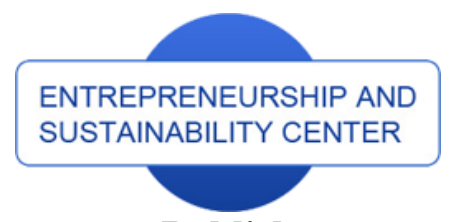

Publisher

http://jssidoi.org/esc/home

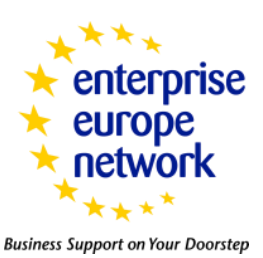

CASPA

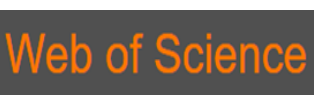

1) Clarivate

\title{
THE ROLE OF GREEN ECONOMY \\ IN SUSTAINABLE DEVELOPMENT (CASE STUDY: THE EU STATES) *
}

\author{
Olga Lavrinenko ${ }^{1}$, Svetlana Ignatjeva ${ }^{2}$, Alina Ohotina ${ }^{3}$, Oleg Rybalkin ${ }^{4}$, Dainis Lazdans ${ }^{5}$ \\ ${ }^{1,3}$ Daugavpils University, Institute of Humanities and Social Sciences, Parades Str. 1-421, Daugavpils, LV-5401, Latvia \\ 2,4,5 Daugavpils University, Computer Science Department, Parades Str. 1-413, Daugavpils, LV-5401, Latvia \\ E-mails: ${ }^{1}$ olga.lavrinenko@du.lv $;{ }^{2} \frac{\text { svetlana.ignatjeva@du.lv }}{{ }^{5} \text { dainis.laz.dans@gmail.com }}$
}

Received 17 August 2018; accepted 20 January 2019; published 30 March 2019

\begin{abstract}
The analysis of various "green" concepts has historically been linked to a broader discussion of the relationship between sustainable development and the environment. Some authors believe that the solution to the problem of the impact on the planet's environment is to reduce the level of economic activity, which would mean severe restrictions in the use of resources. Others think that economic activity can continue to grow, but with less impact on the environment; some experts claim that it is quite possible to achieve a balance between economic growth and care for the planet and people. In this context, it is necessary to use a new paradigm that clearly states that "environment" and" economic growth" cannot be seen as conflicting goals, which is confirmed by the authors of the article who studied the situation in the EU countries in the period 2016-2017.
\end{abstract}

Key terms: sustainable development; Quintuple Helix model; green economy; the EU

Reference to this paper should be made as follows: Lavrinenko, O.; Ignatjeva, S.; Ohotina, A.; Rybalkin, O.; Lazdans, D. 2019. The Role of Green Economy in Sustainable Development (Case Study: The EU States), Entrepreneurship and Sustainability Issues 6(3): 1113-1126. http://doi.org/10.9770/jesi.2019.6.3(4)

JEL Classification: C43, O44, O52, O57, R11, Q20, Q30

\section{Introduction}

The idea of sustainable development and environmentally oriented economy which emerged in the second half of the $20^{\text {th }}$ century in the international scientific community, for example, ideas of the Club of Rome, then rapidly spread to all continents. The entire end of the $20^{\text {th }}$ century and the beginning of the $21^{\text {st }}$ century can be represented

\footnotetext{
* This article is published within the research project of Daugavpils University "Green Economy: Elaboration of the Concept and Approbation of the Assessment Methodologies on the Basis of the EU Data", Nr. 14-95/18
} 


\section{ENTREPRENEURSHIP AND SUSTAINABILITY ISSUES}

ISSN 2345-0282 (online) http://jssidoi.org/jesi/

2019 Volume 6 Number 3 (March)

http://doi.org/10.9770/jesi.2019.6.3(4)

as a series of global forums which polished and refined this paradigm as the only possible, main path for development of the entire planetary system.

Back in the late 1980s and early 1990s, new conceptual approaches to the development of society and economy emerged within the framework of the UN structures, in particular, a new theory that had a huge impact on the discussion of new models: sustainable development. The UN Conference on Sustainable Development ("Rio+20") held in Rio de Janeiro in June 2012, which was the largest UN conference in the $21^{\text {st }}$ century, actually summarized the outcomes of attempts that had been made for twenty years, to change the traditional type of development to a model of sustainable development. The conference's greatest achievement was the recognition of the fact that problems of environment and development could not any longer be considered taken separately. The transition to sustainable development implies the preservation of natural ecosystems at a level that ensures the implementation of the needs of present and future generations of people, while maintaining the stability of the ecosystems themselves (the entire ecosphere as a whole). There were five documents adopted at the conference, the most significant ones being "The Rio Declaration on Environment" and "Agenda 21". In accordance with "Agenda 21", governments around the world must develop their national strategies for sustainable development Local Agenda 21 (The World Bank 2012).

Sustainable development in general is a continuous process of satisfying needs of the present and future generations. The definition is unanimously accepted, alas ways of implementation of this approach towards development is under continuous discussion (Tvaronavičienè et al. 2015; Strielkowski et al. 2016; Tvaronavičiené 2017; Vegera et al. 2018; Stjepanović et al. 2017; Razminienè, Tvaronavičiene் 2018; Tvaronavičienè 2018; Eddelani et al. 2019).

The economic content of sustainable development is a process of managing a set (portfolio) of assets targeted at preserving and expanding the opportunities available to people. Sustainable development implies, first and foremost, changes in three main areas - finance, social responsibility, and ecology, which are interrelated and interdependent (Rosha, Lace 2015; Ohotina et al. 2018). At the same time, the concept "sustainable development" is usually considered from two perspectives. In a narrow sense, the attention is mainly focused on its ecological component, but in a broad sense, sustainable development is interpreted as a process that denotes a new type of functioning of the civilization. Therefore, sustainable development is an objective requirement of our time. Balanced development may be considered as part of the concept "sustainable development"; it means a justification for the balance of common priorities (factors) of development (resource, social, economic, environmental, legal, cultural, environmental) in a particular organization and their harmonization with the interests of sectoral, regional and national development. Focusing on the ideas of the process approach, management of sustainable development is a set of techniques, methods, and procedures of the targeted impact that provide a qualitative transformation of the system in the conditions of evolutionary functioning. Sustainable development is a new type of functioning of the production and economic system (society, organization, industry, etc.) that enables to ensure strategic competitiveness over the long term (Kozhevina 2015; Aleksejeva 2016).

The world is now facing the global challenges of a rapidly growing population and the increasing pressure on the environment related to it that should be prevented (Kasztelan 2017). The concept of "green economy" includes ideas of many other approaches in economics and philosophy related to the issues of sustainable development. Supporters of the "green economy" concept believe that the economic system prevailing now is imperfect, although it has produced some considerable results in improving people's living standards. However, it also resulted in a number of environmental problems (climate change, desertification, loss of biodiversity), depletion of natural capital, large-scale poverty, lack of fresh water, food, energy, inequality of people and countries. The survival and development of humanity requires the transition to "green economy". This is a system of economic activities related to the production, distribution and consumption of goods and services that lead to the increase in 


\section{ENTREPRENEURSHIP AND SUSTAINABILITY ISSUES}

ISSN 2345-0282 (online) http://jssidoi.org/jesi/

2019 Volume 6 Number 3 (March)

http://doi.org/10.9770/jesi.2019.6.3(4)

human well-being in the long term, but at the same time without exposing future generations to significant environmental risks or environmental deficits.

The concept of "green economy" appeared more than 20 years ago (Pearce et al. 1989; Barbier 2009). The implementation of the green economy concept was described as a long-term strategy for national economies to overcome the crisis (Barbier 2009), with the objectives of economic recovery; poverty eradication; as well as reducing carbon emissions, and stopping the degradation of ecosystems.

The UNEP (UNEP 2011) considers a "green economy" as the economy that leads to the improvement of human well-being and social justice and which does not have any ecological downsides. At the operational level, the green economy is designed to reduce carbon emissions and pollution; to improve the efficiency of energy and resource usage; and "... it aims to promote economic growth and development while ensuring the use of natural assets for sustainable development" (UNEP 2011) and it supports the progress of social development ... “(International Chamber of Commerce 2012). “...The economy where the growth of the people's welfare and employment increase are provided owing to the state and social investments ensuring reduction of emissions and environmental pollution and stimulating effective use of energy and resources as well as preventing any harm to biodiversity and ecosystem" (Diyar et al. 2014; Stjepanović et al. 2017; Smaliukiene, Monni 2019).

The Global Environmental Forum in Nusa Dua recognized the UNEP's leading role in promoting the green economy concept (Allen, Clouth 2012; ) which leads to the improvement of human well-being and social justice, while significantly decreasing ecological risks and deficiencies, at the same time being low-carbon, resource efficient, and socially inclusive (UNEP 2010). Therefore, a green growth corresponding to the green economy concept inevitably leads to sustainable development (Kasztelan 2017, Ohotina 2016). However, it is necessary to continue performing certain tasks for the development of global models and scenarios in order to assess strategies for national "green economy" and "green" growth (Kasztelan 2017).

The aim of this research is to assess the sustainable development in the EU countries, as well as to assess the importance of the green economy factor in the model of sustainable development in the EU countries in the period 2016-2017.

\section{Methodology}

The only way to solve global problems related to the increasing pressure on the environment is the use of the assets of human knowledge (Carayannis and Campbell 2010; Bhaskar 2010). "The Quintuple Helix" model is one of the models based on the quality management of effective development, restoring balance with nature and preserving Earth's biological diversity. It can solve existing problems applying knowledge and know-how, as it focuses on the social (public) exchange and transfer of knowledge within the subsystems of a particular state or a national state (Barth 2011a). The innovative model Quintuple Helix explains in what way knowledge, innovations, and environment (natural environment) are interrelated (Carayannis and Campbell 2010; Barth 2011a). The Quintuple Helix model is both interdisciplinary and transdisciplinary: the complexity of the fivespiral framework implies that a full analytical understanding of all spirals requires the continuous involvement of the entire disciplinary spectrum, ranging from Natural Sciences (due to the natural environment) to Social Sciences and Humanities, to promote and visualize the system of collaboration between knowledge, know-how, and innovations for more sustainable development (Carayannis and Campbell, 2010). Therefore, the specific character of the model can be described in the following way (see Fig.1).

The first subsystem is the system of education where the necessary "human capital" is formed. The second subsystem - the economic one - concentrates and focuses the "economic capital" (e.g. entrepreneurship, machines, food, technologies, and money). The third subsystem - the political one, i.e. the "political and legal 
capital" (e.g. ideas, laws, plans, policies, etc.). The fourth subsystem unites two forms of "capital" - the "social capital" and the "information capital". The fifth subsystem - the environment is crucial for sustainable development and it provides people with the "natural capital" (e.g. resources, plants, animal diversity, etc.).

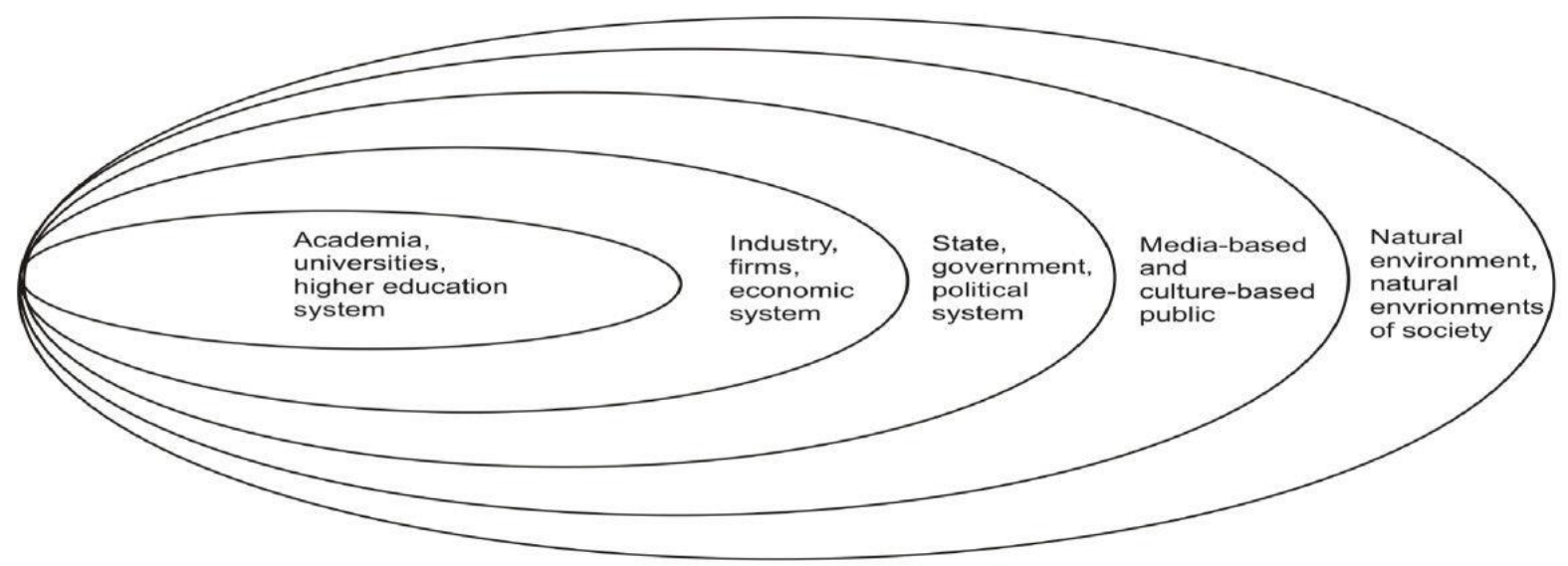

Fig.1. The subsystems of the Quintuple Helix model.

Source: Carayannis et al. 2012; Etzkowitz and Leydesdorff 2000; Carayannis and Campbell, 2009, 2010.

All subsystems in the Quintuple Helix perform functions which influence each other. In the innovative Quintuple Helix model, the natural environment is defined as an opportunity for further development and provision of sustainable development and co-evolution of the knowledge economy, knowledge society and democracy, which also influences the way we perceive and organize entrepreneurship (Etzkowitz and Leydesdorff 2000; Carayannis and Campbell 2006, 2009, 2010; Barth 2011).

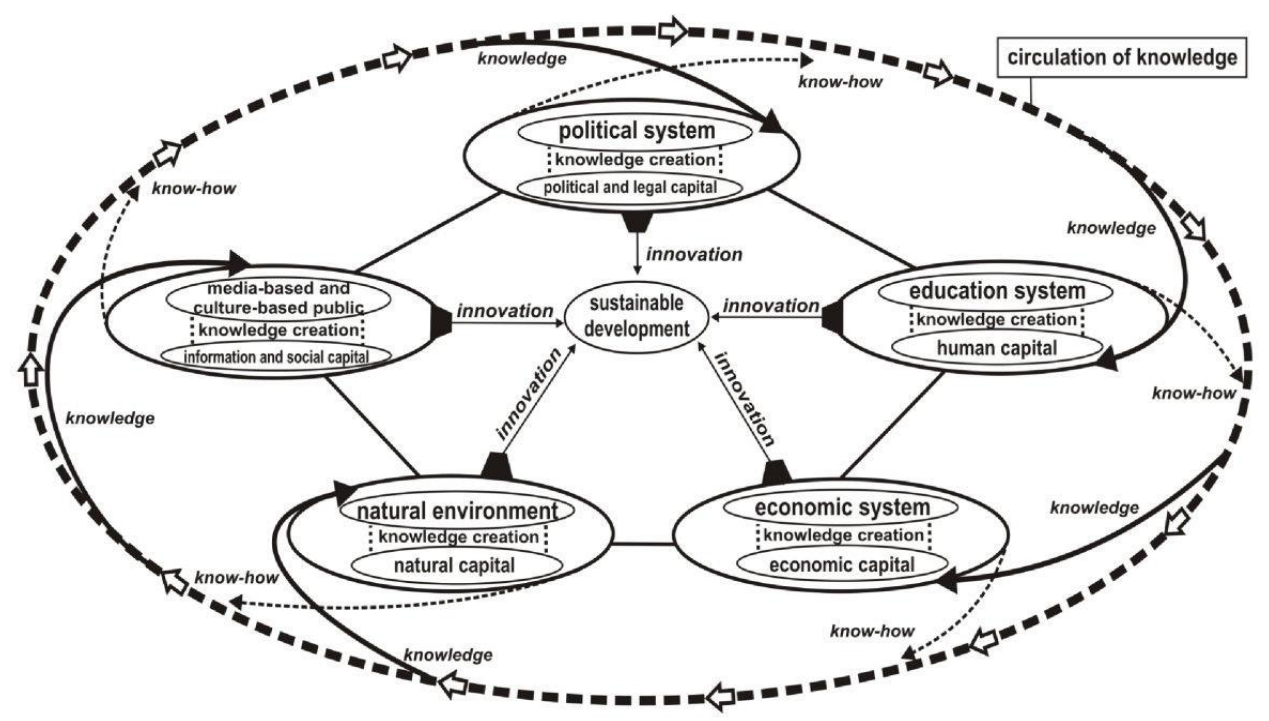

Figure. 2. The Quintuple Helix model and its function (functions).

Source: created by autors by Carayannis et al. 2012 


\section{ENTREPRENEURSHIP AND SUSTAINABILITY ISSUES}

ISSN 2345-0282 (online) http://jssidoi.org/jesi/ 2019 Volume 6 Number 3 (March) http://doi.org/10.9770/jesi.2019.6.3(4)

The set of all available statistical and integrated indicators corresponding to the Quintuple Helix model (see Annex 1) in the EU countries for 2016 or 2017 comprised the empirical base of the research. All indicators were standardized, and then, in order to perceive them better, the transition to $\mathrm{T}$ scale by the formula $\mathrm{T}=50+10 * \mathrm{z}$ was made. Factors corresponding to the Quintuple Helix model are obtained as arithmetic means of the corresponding indicators; the integrated Quintuple Helix model indicator is obtained as the arithmetic mean of the values of five subsystems. The correlations between the factors are presented in Appendix 2.

\section{Research results}

Sweden is a leader according to mean values of the five subsystems (60.57). The top six countries also include Denmark and Germany (58.41 and 58.35 respectively), the United Kingdom (57.69), Finland (57.43), and the Netherlands (56.41). Romania (42.90), Poland (43.19), Cyprus (43.54), Bulgaria (43.67), and Hungary (44.34) are at the bottom according to the assessment of the subsystems. The cluster analysis carried out in the obtained fivefactor space allowed to group all EU countries into two homogeneous clusters (see Fig. 1). The first cluster (CL+) includes 13 countries which are characterized by higher indicators according to all five subsystems; other 15 countries (CL-) are characterized by a lower level of these indicators. The first cluster (CL+) mainly includes the so-called "old" EU countries: Denmark, Germany, Ireland, Spain, France, Italy, Luxemburg, the Netherlands, Austria, Slovenia, Finland, Sweden, the United Kingdom.

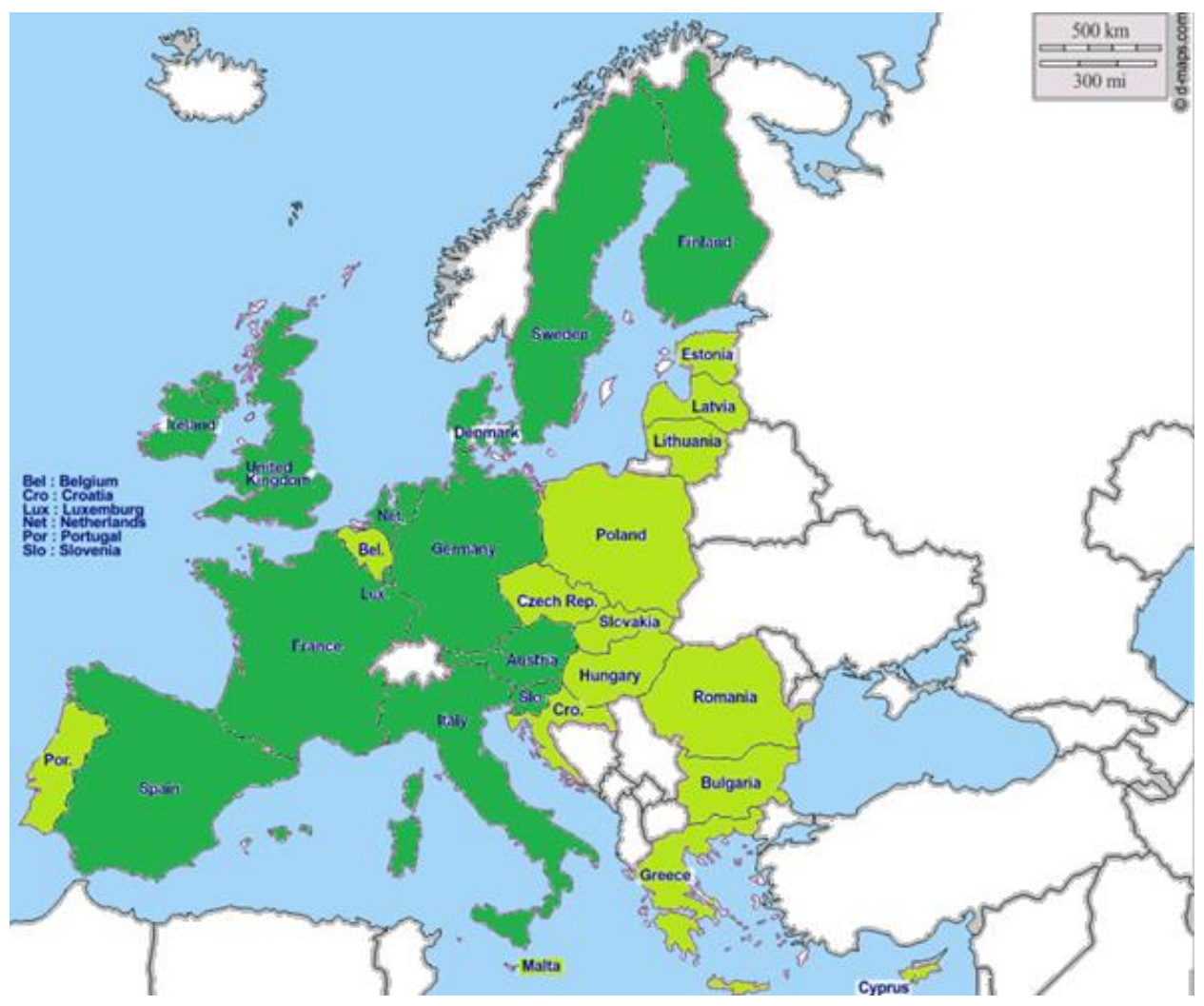

Figure 3. The EU countries included in CL+, CL- clusters of a five-factor space of the Quintuple Helix model's subsystems in 2016-2017

Source: the authors calculations in SPSS according to statistical data 
ISSN 2345-0282 (online) http://jssidoi.org/jesi/ 2019 Volume 6 Number 3 (March) http://doi.org/10.9770/jesi.2019.6.3(4)

The second cluster (CL-) mainly includes the countries in Central and Eastern Europe which joined the EU later: Belgium, Bulgaria, Czech Republic, Estonia, Greece, Croatia, Cyprus, Latvia, Lithuania, Hungary, Malta, Poland, Portugal.

Considering the mean values of subsystems according to the clusters, it can be concluded that all mean values of subsystems in the CL+ cluster considerably exceed the mean values of subsystems in the CL-cluster: the mean value of the "political" subsystem by $15.4 \%$, the mean value of the "civil society" subsystem $22.6 \%$, the "natural environment" subsystem by $7.8 \%$, the "economic aspects" subsystem by $15.2 \%$, the "quantify of education system" subsystem by $21.2 \%$ (see Fig. 4).

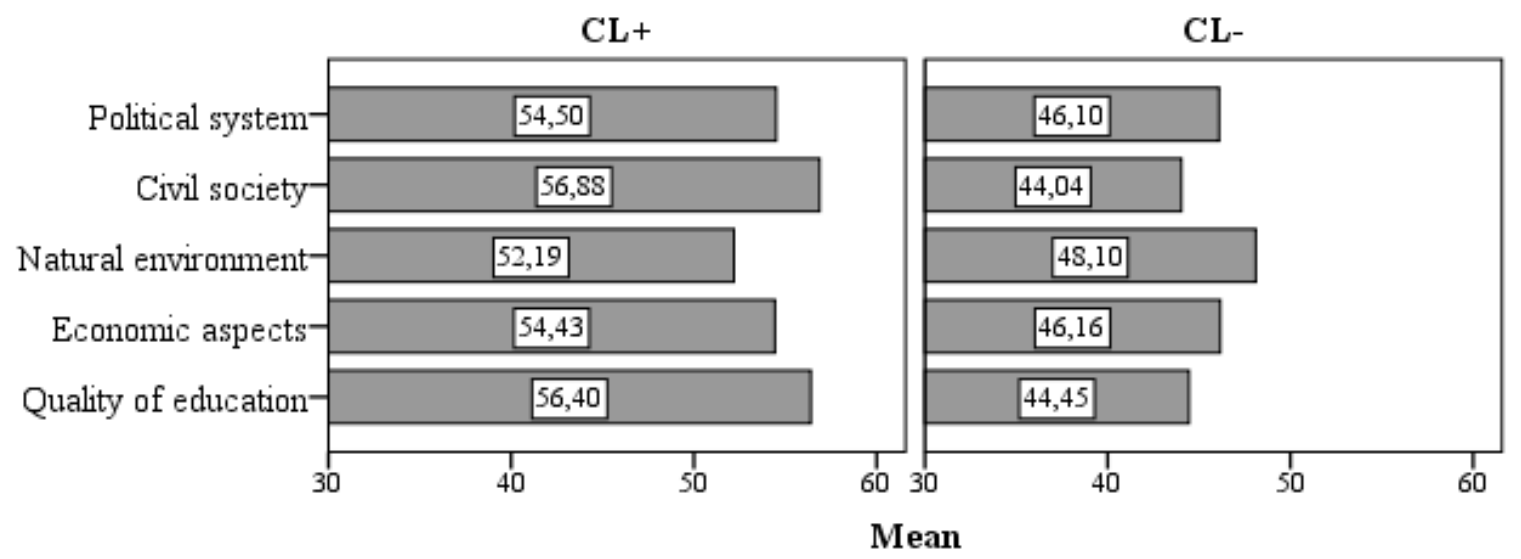

Figure.4. Mean values of the Quintuple Helix model's systems in 2016-2017 according to the clusters. Source: the authors' calculations in SPSS according to statistical data

Sweden is a leader according to the values of the five subsystems in the CL+ cluster, Italy is at the bottom of the list. The United Kingdom is a leader in the "Quantify of education system" subsystem (73.89), Luxemburg is at the bottom of the list(43.59); Sweden is a leader in the "Economic aspects" subsystem (60.54), Slovenia is at the bottom of the list (49.29); Slovenia and Austria are leaders of the "Natural environment" subsystem (56.88 and 56.85 respectively), Ireland is at the bottom of the list (48.35); Sweden is a leader of the "Civil society" subsystem (67.77), Slovenia is at the bottom of the list (45.62); Sweden is a leader in the "Political system" subsystem (63.34), Ireland is at the bottom of the list (47.86) (see Table1).

Table 1. Values of the cluster CL+ Quintuple Helix model's subsystems in 2016-2017

\begin{tabular}{|c|c|c|c|c|c|c|c|}
\hline & Country name & $\begin{array}{c}\text { Quantify of } \\
\text { education } \\
\text { system }\end{array}$ & $\begin{array}{c}\text { Economic } \\
\text { aspects }\end{array}$ & $\begin{array}{c}\text { Natural } \\
\text { environment }\end{array}$ & $\begin{array}{c}\text { Civil } \\
\text { society }\end{array}$ & $\begin{array}{c}\text { Political } \\
\text { system }\end{array}$ & Mean \\
\hline 1 & Denmark & 56.06 & 55.24 & 53.64 & 66.14 & 60.95 & 58.41 \\
\hline 2 & Germany & 66.10 & 56.43 & 52.45 & 62.13 & 54.66 & 58.35 \\
\hline 3 & Ireland & 50.94 & 53.39 & $\mathbf{4 8 . 3 5}$ & 56.75 & $\mathbf{4 7 . 8 6}$ & 51.46 \\
\hline 4 & Spain & 56.71 & 52.84 & 48.67 & 51.73 & 50.71 & 52.13 \\
\hline 5 & France & 60.65 & 52.29 & 51.75 & 51.99 & 55.90 & 54.52 \\
\hline 6 & Italy & 54.42 & 53.18 & 48.73 & 46.33 & 48.09 & 50.15 \\
\hline 7 & Luxemburg & $\mathbf{4 3 . 5 9}$ & 54.63 & 55.12 & 53.71 & 50.92 & 51.59 \\
\hline 8 & Netherlands & 60.93 & 55.59 & 49.30 & 62.12 & 54.10 & 56.41 \\
\hline
\end{tabular}


ENTREPRENEURSHIP AND SUSTAINABILITY ISSUES

ISSN 2345-0282 (online) http://jssidoi.org/jesi/

2019 Volume 6 Number 3 (March)

http://doi.org/10.9770/jesi.2019.6.3(4)

\begin{tabular}{|c|c|c|c|c|c|c|c|}
\hline 9 & Austria & 51.90 & 52.88 & $\mathbf{5 6 . 8 5}$ & 55.58 & 54.29 & 54.30 \\
\hline 10 & Slovenia & 45.21 & $\mathbf{4 9 . 2 9}$ & $\mathbf{5 6 . 8 8}$ & $\mathbf{4 5 . 6 2}$ & 55.13 & 50.43 \\
\hline 11 & Finland & 55.38 & 55.04 & 52.15 & 63.36 & 61.20 & 57.43 \\
\hline 12 & Sweden & 57.41 & $\mathbf{6 0 . 5 4}$ & 53.78 & $\mathbf{6 7 . 7 7}$ & $\mathbf{6 3 . 3 4}$ & $\mathbf{6 0 . 5 7}$ \\
\hline 13 & $\begin{array}{c}\text { United } \\
\text { Kingdom }\end{array}$ & $\mathbf{7 3 . 8 9}$ & 56.24 & 50.77 & 56.24 & 51.32 & 57.69 \\
\hline \multicolumn{7}{|c|}{ CL5 = CL+ } \\
\hline
\end{tabular}

Source: the authors' calculations in SPSS according to statistical data

Belgium is a leader according to the values of the five subsystems in the CL- cluster, Romania is at the bottom of the list. Belgium is a leader in the "Quantify of education system" subsystem (54.84), Croatia is at the bottom of the list(40.51); Belgium is a leader in the "Economic aspects" subsystem (48.99), Poland is at the bottom of the list (42.94); Croatia is a leader of the "Natural environment" subsystem (52.98), Belgium is at the bottom of the list (43.25); Belgium is a leader of the "Civil society" subsystem (51.47), Bulgaria is at the bottom of the list (36.73); Portugal is a leader in the "Political system" subsystem (53.36), Cyprus is at the bottom of the list (40.11) (see Table 2).

Table 2. Values of the cluster CL- Quintuple Helix model's subsystems in 2016-2017

\begin{tabular}{|c|c|c|c|c|c|c|c|}
\hline Country name & $\begin{array}{c}\text { Quantify of } \\
\text { education } \\
\text { system }\end{array}$ & $\begin{array}{c}\text { Economic } \\
\text { aspects }\end{array}$ & $\begin{array}{c}\text { Natural } \\
\text { environment }\end{array}$ & $\begin{array}{c}\text { Civil } \\
\text { society }\end{array}$ & $\begin{array}{c}\text { Political } \\
\text { system }\end{array}$ & Mean \\
\hline 1 & Belgium & $\mathbf{5 4 . 8 4}$ & $\mathbf{4 8 . 9 9}$ & $\mathbf{4 3 . 2 5}$ & $\mathbf{5 1 . 4 7}$ & 47.26 & $\mathbf{4 9 . 1 6}$ \\
\hline 2 & Bulgaria & 41.85 & 44.82 & 50.75 & $\mathbf{3 6 . 7 3}$ & 44.20 & 43.67 \\
\hline 3 & Czech Republic & 46.48 & 48.01 & 48.46 & 47.76 & 43.39 & 46.82 \\
\hline 4 & Estonia & 46.27 & 46.47 & 51.46 & 49.99 & 50.55 & 48.95 \\
\hline 5 & Greece & 46.09 & 45.69 & 48.70 & 40.15 & 48.13 & 45.75 \\
\hline 6 & Croatia & $\mathbf{4 0 . 5 1}$ & 45.27 & $\mathbf{5 2 . 9 8}$ & 37.90 & 51.49 & 45.63 \\
\hline 7 & Cyprus & 42.13 & 45.85 & 43.58 & 46.05 & $\mathbf{4 0 . 1 1}$ & 43.54 \\
\hline 8 & Latvia & 41.69 & 43.86 & 50.95 & 45.44 & 49.82 & 46.35 \\
\hline 9 & Lithuania & 43.67 & 44.91 & 46.74 & 44.76 & 46.21 & 45.26 \\
\hline 10 & Hungary & 42.47 & 47.73 & 47.75 & 38.16 & 45.60 & 44.34 \\
\hline 11 & Malta & 44.13 & 47.17 & 47.99 & 46.13 & 42.83 & 45.65 \\
\hline 12 & Poland & 46.21 & $\mathbf{4 2 . 9 4}$ & 43.83 & 39.78 & 43.21 & 43.19 \\
\hline 13 & Portugal & 48.35 & 48.00 & 45.57 & 50.01 & $\mathbf{5 3 . 3 6}$ & 49.06 \\
\hline 14 & Romania & 40.79 & 45.92 & 47.68 & 39.36 & 40.76 & $\mathbf{4 2 . 9 0}$ \\
\hline 15 & Slovakia & 41.32 & 46.78 & 51.87 & 46.84 & 44.59 & 46.28 \\
\hline
\end{tabular}

Source: the authors' calculations in SPSS according to statistical data

The assessment of the contribution of each subsystem to the sustainable development model is estimated by calculating the correlation coefficients of the Quintuple Helix model's subsystems in 2016-2017 with the mean value of all 5 subsystems:

Table 3. The correlation coefficients of the values of the Quintuple Helix model's subsystems in 2016-2017 with a mean value of all subsystems 
ENTREPRENEURSHIP AND SUSTAINABILITY ISSUES

ISSN 2345-0282 (online) http://jssidoi.org/jesi/

2019 Volume 6 Number 3 (March)

http://doi.org/10.9770/jesi.2019.6.3(4)

\begin{tabular}{|l|l|l|l|}
\hline Quantify of education system & $0.315(\mathrm{p}$-value 0.000$)$ & $\mathbf{0 . 4 6 9}(\mathrm{p}$-value 0.000$)$ & $0.355(\mathrm{p}$-value 0.000$)$ \\
\hline Economic aspects & $0.183(\mathrm{p}$-value 0.000$)$ & $0.166(\mathrm{p}$-value 0.000$)$ & $0.174(\mathrm{p}$-value 0.000$)$ \\
\hline Natural environment & $\mathbf{0 . 1 4 5}(\mathrm{p}$-value 0.000$)$ & $\mathbf{0 . 1 9 6}(\mathrm{p}$-value 0.000$)$ & $\mathbf{0 . 2 9 7}(\mathrm{p}$-value 0.000$)$ \\
\hline Civil society & $0.310(\mathrm{p}$-value 0.000$)$ & $0.386(\mathrm{p}$-value 0.000$)$ & $\mathbf{0 . 4 6 7}$ (p-value 0.000$)$ \\
\hline Political system & $0.229(\mathrm{p}$-value 0.000$)$ & $0.269(\mathrm{p}$-value 0.000$)$ & $0.393(\mathrm{p}$-value 0.000$)$ \\
\hline
\end{tabular}

Source: the authors' calculations in SPSS according to statistical data

Therefore, there is a weak positive linear dependence of the indicator that characterizes sustainable development on the sub-component "Natural environment" in the EU countries. However, in the CL- cluster this dependence is slightly stronger than in the CL+ cluster. The authors found interesting the fact that the sub-component "Civil society" has the most impact on sustainable development in the CL- cluster, whereas the sub-component "Quantify of education system" affects sustainable development the most in the CL+ cluster.

\section{Discussion and conclusions}

Many researchers made the assessment of "green economy". For example, in the research (Kasztelan 2017) founded on 33 selected indicators of "green economy" on the basis of the OECD methodologies and database, the level of green growth of selected 21 OECD member countries was determined by means of one of the most popular taxonomic methods - the Hellwig's pattern model (Hellwig 1968). The reference years 2010-2014 were chosen due to the data availability. Diagnostic variables defining the level of green growth for particular countries were adjusted in an attempt to meet three criteria: substantive, formal, and statistical. Based on the results obtained, the author concludes that the green growth can provide solutions to economic and environmental problems and create new sources for growth (Kasztelan 2017; Šipilova et al. 2017), however, its level in the OECD countries is still insufficient (Kasztelan 2017). Denmark was awarded the highest score, followed by Germany and Sweden. The United Stated are characterized by the lowest level of the green growth. Examining 23 EU countries on the basis of 26 indicators in the period 2010-2014 (Kasztelan 2016), A. Kasztelan (Kasztelan 2016) applying the abovementioned methods determined that 5 countries related to Group I - Sweden, Finland, Latvia, Denmark, and Italy - were awarded the highest synthetic score of the green growth level. Group II consisting of 6 states - Estonia, Austria, Lithuania, the Netherlands, Slovenia, and Spain had an outstanding green growth level. Group III which demonstrated the average level of green growth was the most numerous and included Slovakia, Romania, Germany, France, the Czech Republic, Portugal, Hungary, the United Kingdom, Poland, and Belgium. Group IV which is characterized by the lowest green growth level among the countries included only two countries - Bulgaria and Cyprus. In the 2018 research Kasztelan (Kasztelan 2018) analyzing the green growth level in 28 EU countries applying the same methods, determined 4 groups of countries: Sweden (0.6477) is the leader, followed by the countries from the second group Croatia (0.5668), Latvia (0.5447), Austria (0.5399), Finland (0.5383), the Netherlands (0.5249), Slovenia (0.4925), Denmark (0.4874), Hungary (0.4808), Belgium (0.4777), Italy (0.4722), and the United Kingdom (0.4666). Slovakia (0.4647), Lithuania (0.4589), the Czech Republic (0.4570), Luxembourg (0.4538), Germany (0.4521), Portugal (0.4469), Spain (0.4461), Poland (0.4406), France (0.4336), Ireland (0.41 TJ.), Estonia (0.4038), and Romania (0.4015) belong to the third group. The fourth group countries Greece (0.3913), Malta (0.3865), Bulgaria (0.3755), and Cyprus (0.3614) are at the bottom. Therefore, there are both similar trends in the assessment of the green economy presented in this research and other studies, and differences due, in the opinion of the authors, the method of creating the index, the time period, as well as the of the countries under research.

The authors proved the positive role of "green economy" in the sustainable development in the EU countries in the period 2016-2017. "Green economy" as part the concept of sustainable development Quintuple Helix model possesses a significant potential. It is possible to draw similar conclusions analyzing the findings of the research carried out by other authors (Kasztelan 2015). 


\section{ENTREPRENEURSHIP AND SUSTAINABILITY ISSUES}

ISSN 2345-0282 (online) http://jssidoi.org/jesi/

2019 Volume 6 Number 3 (March)

http://doi.org/10.9770/jesi.2019.6.3(4)

\section{References}

Aleksejeva L. 2016. Country's Competitiveness and Sustainability: Higher Education Impact. Journal of Security and Sustainability Issues 5(3): 355-363. https://doi.org/10.9770/jssi.2016.5.3(4)

Barbier, E. B. 2009. Rethinking the Economic Recovery: A Global Green New Deal. Report prepared for the Economics and Trade Branch, Division of Technology, Industry and Economics, UNEP. https://www.cbd.int/development/doc/UNEP-global-green-new-deal.pdf

Barth, T.D. 2011. The idea of a green new deal in a Quintuple Helix Model of knowledge, know-how and innovation. International Journal of Social Ecology and Sustainable Development 1(2):1-14.

Carayannis, E.G. (Ed)/ 2011. In Planet earth 2011 - global warming challenges and opportunities for policy and practice. Open Access Publisher. https://www.intechopen.com/books/planet-earth-2011-global-warming-challenges-and-opportunities-for-policy-and-practice

Carayannis, E. G.; Barth, T. D.; Campbell, D. F. J. 2012. The Quintuple Helix innovation model: global warming as a challenge and driver for innovation. Journal of Innovation and Entrepreneurship, 1 (2), 1-12. https://link.springer.com/article/10.1186/2192-5372-1-2

Carayannis, E. G., Barth, T. D., Campbell, D. F .J. 2012. The Quintuple Helix innovation model: global warming as a challenge and driver for innovation. Journal of Innovation and Entrepreneurship, 1 (2) (Modified from Etzkowitz and Leydesdorff (2000), p. 111) and Carayannis and Campbell (2009), p. 207; 2010, p. 62)). https://innovation-entrepreneurship.springeropen.com/articles/10.1186/2192-5372$\underline{1-2}$

Carayannis, E. G.; Campbell, D. F. J. 2009."Mode 3" and "Quadruple Helix": toward a 21st century fractal innovation ecosystem. International Journal of Technology Management 46(3/4):201-234. Available on internet: https://www.researchgate.net/publication/240295704 'Mode 3' and 'Quadruple Helix' Toward a 21st century fractal innovation ecosy $\underline{\text { stem }}$

Carayannis, E. G.; Campbell, D. F. J. 2010. Triple Helix, Quadruple Helix and Quintuple Helix and how do knowledge, innovation and the environment relate to each other? A proposed framework for a trans-disciplinary analysis of sustainable development and social ecology. International Journal of Social Ecology and Sustainable Development 1(1):41-69. Available on internet: https://www.igiglobal.com/article/triple-helix-quadruple-helix-quintuple/41959

Carayannis, E.G., Campbell, D. F. J. 2011. Open innovation diplomacy and a 21st century fractal research, education and innovation (FREIE) ecosystem: building on the Quadruple and Quintuple Helix innovation concepts and the "Mode 3" knowledge production system. Journal of the Knowledge Economy 2(3):327-372. Available on internet: https://link.springer.com/article/10.1007\%2Fs13132-011-0058-3

Carayannis, E. G., Campbell, D. F. J. 2012. Mode 3 knowledge production in quadruple helix innovation systems. 21st-century democracy, innovation, and entrepreneurship for development. SpringerBriefs in business (Vol. 7). Springer, New York. Available on internet: https://www.springer.com/la/book/9781461420613

Carayannis, E. G., Campbell, David F.J., Orr, B.J. 2016. Democracy and environment as references for quadruple and quintuple helix innovation systems. Retrieved February 10, from http://meetingorganizer.copernicus.org/EGU2015/EGU2015-15497-1.pdf

Carayannis, E. G.; Kaloudis, A. 2010. 21st century democratic capitalism: a time for action and a time to lead.International Journal of Social Ecology and Sustainable Development 1(1):1-13. https://www.igi-global.com/article/21st-century-democratic-capitalism/41955

Climate Change Performance Index. 2018. Available on internet: https://www.climate-change-performanceindex.org/sites/default/files/documents/the_climate_change_performance_index_2018.pdf

Diyar, S., Akparova, A., Toktabayev, A., Tyutunnikova, M. 2014. Green Economy - Innovation Based Development of Kazakhstan. Procedia - Social and Behavioral Sciences, 140, 695-699. Available on internet: https://doi.org/10.1016/j.sbspro.2014.04.497

Eddelani, O.; El Amrani El Idrissi, N.; Monni, S. 2019. Territorialized forms of production in Morocco: provisional assessment for an own model in gestation, Insights into Regional Development 1(1): 6-18. http://doi.org/10.9770/IRD.2019.1.1(1)

Etzkowitz, H., Leydesdorff, L. 2000. The dynamics of innovation: from National Systems and "Mode 2" to a Triple Helix of universityindustry-government relations. Research Policy 29: 109-123. 10.1016/S0048-7333(99)00055-4. Available on internet: https://www.sciencedirect.com/science/article/abs/pii/S0048733399000554 


\section{ENTREPRENEURSHIP AND SUSTAINABILITY ISSUES}

ISSN 2345-0282 (online) http://jssidoi.org/jesi/

2019 Volume 6 Number 3 (March)

http://doi.org/10.9770/jesi.2019.6.3(4)

Eurostat. Environmental tax revenues. Available on internet:

http://ec.europa.eu/eurostat/tgm/table.do?tab=table\&init=1\&language=en\&pcode=t2020 rt320\&plugin=1

Eurostat. Resource productivity and domestic material consumption (DMC). Available on internet:

http://ec.europa.eu/eurostat/tgm/refreshTableAction.do?tab=table\&plugin=1\&pcode=sdg_12_20\&language=en

Global green economy index. 2016. Available on internet: http://dualcitizeninc.com/GGEI-2016.pdf

Hellwig, Z. 1968. Application of the Taxonomic Method to the Countries Typology according to their Level of Development and the Structure of Resources and Qualified Staff (in Polish). Przegląd Statystyczny, 4, pp. 307-326.

https://www.researchgate.net/publication/320566883/

Inclusive Green Growth: The Pathway to Sustainable Development. - Washington, D.C.: The World Bank, 2012. - 171 p.

International Chamber of Commerce. 2012. Green Economy Roadmap. A Guide for Business, Policymakers and Society. Document No 213-18/8. https://iccwbo.org/publication/icc-green-economy-roadmap-a-guide-for-business-policymakers-and-society-2012/

Kasztelan, A. 2016. Green competitiveness of the EU countries. Proceedings of the 3rd International Conference on European Integration. pp. 415-424. Publisher: VŠB - Technical University of Ostrava Sokolská třída 33, 70121 Ostrava 1, Czech Republic. Editors: Eva Kovářová, Lukáš Melecký, Michaela Staníčková Cover: Jan Pražák ISBN 978-80-248-3911-0 . Available on internet: https://www.ekf.vsb.cz/export/sites/ekf/icei/.content/galerie-dokumentu/ICEI-2016_Sbornik_Komplet_Web_FINAL.pdf

Kasztelan, A. 2015. Natural Capital as a Factor in Regional Competitiveness. Miscellanea Geographica - Regional Studies on Development, 19(3): 63-69. https://doi.org/10.1515/mgrsd-2015-0010

Kasztelan, A. 2017. Green Growth, Green Economy and Sustainable Development: Terminological and Relational Discourse, Prague Economic Papers, 26(4), 487-499. Available on internet: https://www.vse.cz/pep/626

Kasztelan, A. 2018. Multi-Criteria Analysis of Green Competitiveness of the EU Countries. Proceedings of the 4th International Confcrence on European Integration 2018. Publisher: VSB - Technical University of Ostrava Sokolska trlda 33, 70200 Ostrava I, Czech RepubJic. Michaela Stanićkova, Lukaś Melecky, Eva Kovarova, Karefina Dvorokova. Jan Prażak. ISBN 978-80-248-4169-4.ISSN 2571029X. Available on internet: https://www.researchgate.net/profile/Armand_Kasztelan/publication/325323264_Multi-

Criteria Analysis of Green Competitiveness of the EU Countries/links/5b05a18e0f7e9b1ed7e823cc/Multi-Criteria-Analysis-of-GreenCompetitiveness-of-the-EU-Countries.pdf

Kozhevina, O.V. 2015. Sustainable Development and Green Growth in the Agro-Industrial Regions. Business Strategy. 3(11). https://www.strategybusiness.ru/jour/article/viewFile/148/143

Ohotina, A. 2016. Prirodnye resursy kak faktor investicionnogo potenciala: prigranichnye regiony Latvii, Litvy i Belarusi [Natural Resources as a Factor of Investment Potential: Latvia, Lithuania and Belarus Cross Border Regions]. The materials of the International Scientific Conference "Social Sciences for Regional Development 2015". Part I. Issues of Sociology: 111-120. Daugavpils, Daugavpils University. http://humanitiessocial.lv/wp-content/uploads/2016/06/SZF-krajums_I_Sociologijas-aktualitates_2016.pdf

Ohotina, A.; Lavrinenko, O.; Ignatjeva, S.; Lonska, J. 2018. Socio-economic security as a determinant of regional differences in the investment climate in the region, Journal of Security and Sustainability Issues 7(3): 427-438. https://doi.org/10.9770/jssi.2018.7.3(5)

Press Freedom Index. 2017. Available on internet: https://knoema.com/atlas/topics/World-Rankings/World-Rankings/Press-freedomindex?origin=knoema.ru\&_ga=2.89288155.1583144423.1520359088-1692225798.1509810957

Razminienè, K.; Tvaronavičienè, M. 2018. Detecting the linkages between clusters and circular economy, Terra Economicus, 16(4):50-65 http://doi.org/10.23683/2073-6606-2018-16-4-50-65

Rosha, A.; Lace. N. 2015. Sustainable Development and Behavioural Patterns: to Innovations Through Coaching, Journal of Security and Sustainability Issues 5(2): 171-180. https://doi.org/10.9770/jssi.2015.5.2(4)

SJR — SCImago Journal \& Country Rank. 2015. Available on internet: http://www.scimagojr.com/countryrank.php?area=2300

Smaliukiene, R.; Monni, S. 2019. A step-by-step approach to social marketing in energy transition, Insights into Regional Development 1(1): 19-32. http://doi.org/10.9770/IRD.2019.1.1(2) 


\section{ENTREPRENEURSHIP AND SUSTAINABILITY ISSUES}

ISSN 2345-0282 (online) http://jssidoi.org/jesi/

2019 Volume 6 Number 3 (March)

http://doi.org/10.9770/jesi.2019.6.3(4)

Sunina, L., Rivza, B. 2016. The quintuple helix model: way of regional development centres in Latvia to smart public administration. $\begin{array}{lllll}\text { Research } & \text { for } & \text { Development, } & 2: & 135-142 .\end{array}$ http://www2.1lu.1v/research_conf/proceedings2016_vol_2/docs/LatviaResRuralDev_22nd_vol2-135-142.pdf

Šipilova V., Ostrovska I., Jermolajeva E., Aleksejeva L., Oḷehnovičs D. 2017. Evaluation of Sustainable Development in Rural Territories in Latgale Region (Latvia) by Using the Conception of Smart Specialization. Journal of Teacher Education for Sustainability Volume, 19 (1): 82-104. https://doi.org/10.1515/jtes-2017-0006.

Stjepanović, S.; Tomić, D.; Škare, M. 2017. A new approach to measuring green GDP: a cross-country analysis, Entrepreneurship and Sustainability Issues 4(4): 574-590. https://doi.org/10.9770/jesi.2017.4.4(13)

Strielkowski, W.; Lisin, E.; Tvaronavičienė, M. 2016. Towards energy security: sustainable development of electrical energy storage, Journal of Security and Sustainability Issues 6(2): 43-52. http://dx.doi.org/10.9770/jssi.2016.6.2(4)

The Economist Intelligence Unit: Democracy index. 2017. Available on internet: https://pages.eiu.com/rs/753-RIQ438/images/Democracy_Index_2017.pdf

The global innovation index repor. 2017. Available on internet: https://www.globalinnovationindex.org/gii-2017-report

The Travel \& Tourism Competitiveness Report. World Economic Forum. 2017. Available on internet:

http://www3.weforum.org/docs/WEF_TTCR_2017_web_0401.pdf

The Use of the Hellwig's Pattern Model for the Evaluation of Green Growth in OECD Countries By: Kasztelan, Armand Edited by: Soliman, KSConference: 29th International-Business-Information-Management-Association Conference Location: Vienna, AUSTRIA. Date: MAY 03-04, 2017a. Int Business Informat Management Assoc sustainable economic growth, education excellence, and innovation management through vision 2020, vols i-vii. pp: 1035-1044.

The World Bank: QS University Ranking Average Score Top 3 Universities 2017, Normalized Score (Using Min-Max Normalization Into 0-100 Range). Available on internet: https://data.worldbank.org/

Tvaronavičienè, M. 2017. Clusters, innovations and energy efficiency: if relantionship could be traced, Marketing and Management of Innovations 2: 382 - 391 http://doi.org/10.21272/mmi.2017.2-35

Tvaronavičienė, M. 2018. Towards sustainable and secure development: energy efficiency peculiarities in transport sector, Journal of Security and Sustainability Issues 7(4): 719-725. https://doi.org/10.9770/jssi.2018.7.4(9)

Tvaronavičienė, M.; Mačiulis, A.; Lankauskienė, T.;. Raudeliūnienė, J.; Dzemyda, I.. 2015. Energy security and sustainable competitiveness of industry development, Economic research = Ekonomska istraživanja 28(1): 502-516.

http://dx.doi.org/10.1080/1331677X.2015.1082435

Vegera, S.; Malei, A.; Sapeha, I.; Sushko, V. 2018. Information support of the circular economy: the objects of accounting at recycling technological cycle stages of industrial waste, Entrepreneurship and Sustainability Issues 6(1): 190-

210. https://doi.org/10.9770/jesi.2018.6.1(13)

UNEP. 2010. Green Economy: Driving a Green Economy through Public Finance and Fiscal Policy Reform, Working Paper v. 1.0. Available on internet: http://www.greenfiscalpolicy.org/wp-content/uploads/2013/08/Driving-a-Green-Economy-Through-Public-Financeand-Fiscal-Policy-Reform.pdf

UNEP. 2011. Towards a Green Economy: Pathways to Sustainable Development and Poverty Eradication. Available on internet: https://sustainabledevelopment.un.org/content/documents/126GER synthesis en.pdf

World Economic Forum: The Global Competitiveness Report 2017-2018. Available on internet: http://www3.weforum.org/docs/GCR2017-2018/05FullReport/TheGlobalCompetitivenessReport2017\%E2\%80\%932018.pdf

World Energy Council: country's profile. 2017. Available on internet: https://trilemma.worldenergy.org/\#!/countryprofile? country $=$ United $\% 20$ Kingdom \&year $=2017$ 


\section{ENTREPRENEURSHIP AND SUSTAINABILITY ISSUES}

ISSN 2345-0282 (online) http://jssidoi.org/jesi/

2019 Volume 6 Number 3 (March)

http://doi.org/10.9770/jesi.2019.6.3(4)

\section{Appendix 1}

Subsystem 1. In order to quantify the education system of the EU countries we will use such indicators as:

$S \_1 \_1$ Quality of higher education and training, index (World Economic Forum 2018);

S_l_2 Average score of top 3 universities in QS university ranking (The World Bank 2017);

S_l_3 University industry research cooperation, index (The global innovation index report 2017);

S_l_4 Total number of documents in Scopus, Environmental science, 2016 (SJR — SCImago 2017);

S_1_5 Citable documents, 2016 (SJR - SCImago 2017);

S_1_6 Citations, 2016 (SJR - SCImago 2017);

S_l_7 Self-citations, 2016 (SJR - SCImago 2017);

S_1_8 Citations per document, 2016 (SJR - SCImago 2017);

S_1_9 h-index, 2016 (SJR - SCImago 2017).

Subsystem 2. Economic aspects can be measured by the following indicators:

S_2_1 Global innovation index (The global innovation index report 2017);

S_2_2 GDP per unit of energy use (part of GII) (The global innovation index report 2017);

S_2_3 ISO 14001 environmental certificates per bn PPP\$ GDP (part of GII) (The global innovation index report 2017);

S_2_4 Resource productivity and domestic material consumption (DMC), PPS per kilogram, 2016 (Eurostat 2018);

S_2_5 C02 intensity (tCO2) per capita 2017 (World Energy Council 2017);

S_2_6 Alternative and nuclear energy share (World Energy Counci 2017);

$S \_2 \_7$ Global green economy index (Global green economy index 2016);

S_2_8 Markets \& Investment, index (part of GGEI) (Global green economy index 2016);

$S \_2 \_9$ Efficiency sectors (part of GGEI) (Global green economy index 2016).

Subsystem 3. To describe the political system with regard to green innovations the following indicators are used:

S_5_1 Stringency of environmental regulations, index (Travel and Tourism Competitiveness Report 2017);

S_5_2 Enforcement of environmental regulations, index (Travel and Tourism Competitiveness Report 2017);

S_5_3 Environmental treaty ratification, index (part of Travel and Tourism Competitiveness Report 2017);

S_5_4 Leadership \& Climate Change, index (part of Global green economy index 2016);

S_5_5 Climate Change Performance Index 2018 (Climate Change Performance Index 2018);

S_5_6 Environmental performance, index (part of Global innovation index) (The global innovation index report 2017);

S_5_7 Environmental tax revenues \% of GDP 2016 (Eurostat 2018)

Subsystem 4. Civil society can be characterized by:

$S \_4 \_$l Global green economy index perception, index (part of Global green economy index) (Global green economy index 2016);

S_4_2 Press Freedom Index 2017 (Press Freedom Index 2017);

S_4_3 Democracy index 2017 (The Economist Intelligence Unit 2017)

Subsystem 5. Natural environment and its characteristics:

S_3_l Environmental sustainability, index, as part of Travel and Tourism Competitiveness Report (The Travel \& Tourism Competitiveness Report 2017);

$S \_3 \_2$ Atmosphere pollution, particulate matter diameter equals 2,5 or more (part of TTCR) (The Travel \& Tourism Competitiveness Report 2017);

S_3_3 Baseline water stress, index (part of TTCR) (The Travel \& Tourism Competitiveness Report 2017);

S_3_4 Threatened species, \% of total (part of TTCR) (The Travel \& Tourism Competitiveness Report 2017);

S_3_5 Forest cover change, \% (part of TTCR) (The Travel \& Tourism Competitiveness Report 2017);

S_3_6 Wastewater treatment, \% (part of TTCR) (The Travel \& Tourism Competitiveness Report 2017);

S_3_7 Total protected areas, \% of territory (part of TTCR) (The Travel \& Tourism Competitiveness Report 2017); 


\section{ENTREPRENEURSHIP AND SUSTAINABILITY ISSUES}

ISSN 2345-0282 (online) http://jssidoi.org/jesi/

2019 Volume 6 Number 3 (March)

http://doi.org/10.9770/jesi.2019.6.3(4)

S_3_8 Environment index (as part of Global green economy index) (Global green economy index 2016);

S_3_9 Ecological sustainability, index (as part of Global innovation index) (The global innovation report 2017).

\section{Appendix 2}

\section{Pearson Correlation}

\begin{tabular}{|c|c|c|c|c|}
\hline & $\begin{array}{c}\text { Quality of } \\
\text { education }\end{array}$ & $\begin{array}{c}\text { Economic } \\
\text { aspects }\end{array}$ & $\begin{array}{c}\text { Natural } \\
\text { environment }\end{array}$ & Civil society \\
\hline Quality of education & 1 &, $793^{* *}$ &, 170 &, $809^{* *}$ \\
\hline Economic aspects &, $793^{* *}$ & 1 &, $453^{* *}$ &, $889^{* *}$ \\
\hline Natural environment &, 170 &, $453^{*}$ & 1 &, $399^{*}$ \\
\hline Civil society &, $809^{* *}$ &, $889^{* *}$ &, $399^{*}$ & 1 \\
\hline Political system &, $610^{* *}$ &, $663^{* *}$ &, $727^{* *}$ &, $669^{* *}$ \\
\hline
\end{tabular}

*Correlation is significant at the 0.05 level (2-tailed).

\section{Aknowledgements}

This research was supported by the project, which has received funding from Daugavpils University research project "Green Economy: Elaboration of the Concept and Approbation of the Assessment Methodologies on the Basis of the EU Data" (2018) No. 14-95/18 


\section{ENTREPRENEURSHIP AND SUSTAINABILITY ISSUES}

ISSN 2345-0282 (online) http://jssidoi.org/jesi/

2019 Volume 6 Number 3 (March)

http://doi.org/10.9770/jesi.2019.6.3(4)

\section{About conributors:}

Olga LAVRINENKO is Dr. oec, Leading researcher at the Institute of Humanities and Social Sciences of Daugavpils University, Latvia. She has status of experts of the Latvian Council of Science in the field of economics and entrepreneurship. Her research interests: regional economics, sustainable economic development.

ORCID ID: https://orcid.org/0000-0001-7383-3749

Svetlana IGNATJEVA is Dr. phys. Head of Computer Science Department of Daugavpils University, gives lectures and participates in research at Tyumen State University as a visiting foreign specialist. Research interests: development and adaptation of questionnaires; collection, analysis and data processing using Data Mining methods.

ORCID ID: https://orcid.org/0000-0002-3608-8409

Alina OHOTINA is Dr.oec, Researcher at the Institute of Humanities and Social Sciences of Daugavpils University, Latvia. She has the status of Expert of the Latvian Council of Science in the fields of economics and entrepreneurship, sociology and social work. Her research interests: regional economics, investments, investment climate (entrepreneurial enviroment).

ORCID ID: https://orcid.org/0000-0002-2749-2725

Oleg RYBALKIN is Phd student in Econimics of Daugavpils University. His research interests: regional economics, sustainable development, green economy.

ORCID ID: https://orcid.org/0000-0002-7310-4594

Dainis LAZDANS is Msc. env. Planning, Lectuer at the Faculty of Nature Sciences and Mathematic of Daugavpils University, Latvia. He is head of Labaratory of Geomotcis of Daugavpils University. His research interests: environmental planning, geographic information systems, nature protection.

ORCID ID: https://orcid.org/0000-0003-1620-0405

Copyright (C) 2019 by author(s) and VsI Entrepreneurship and Sustainability Center

This work is licensed under the Creative Commons Attribution International License (CC BY).

http://creativecommons.org/licenses/by/4.0/

cC) (7) Open Access 